\title{
Microstructure and Wear Properties of a Low Carbon Bainitic Steel on Plasma Nitriding at Different $\mathrm{N}_{2}-\mathrm{H}_{2}$ Gas Mixtures
}

\author{
Rafael Luciano Dalcin ${ }^{a}$ (D), Alexandre da Silva Rocha ${ }^{a}$ (D), Victor Velho de Castro ${ }^{b}$ (D), \\ Julio Cesar Klein das Neves ${ }^{\text {(D) }, \text { Carlos Henrique da Silva }}{ }^{\text {(D), Ricardo Diego Torres }}{ }^{d}$ (D), \\ Rafael Menezes Nunes ${ }^{a}$ (D), Célia de Fraga Malfatti ${ }^{b}$ \\ ${ }^{a}$ Universidade Federal do Rio Grande do Sul, Laboratório de Transformação Mecânica, Porto Alegre, \\ RS, Brasil. \\ ${ }^{b}$ Universidade Federal do Rio Grande do Sul, Laboratório de Pesquisa em Corrosão, Porto Alegre, RS, \\ Brasil. \\ 'Universidade Tecnológica Federal do Paraná, Laboratório de Superfícies e Contato, Curitiba, PR, \\ Brasil. \\ 'Pontifícia Universidade Católica do Paraná, Departamento de Engenharia Mecânica, Curitiba, PR, \\ Brasil.
}

Received: September 05, 2021; Revised: October 11, 2021; Accepted: October 30, 2021

For the first time, the influence of gas mixture on first damage resistance of a plasma nitrided DIN $18 \mathrm{MnCrSiMo6}-4$ bainitic steel was investigated. Samples were nitrided at $500{ }^{\circ} \mathrm{C}$ with three different $\mathrm{N}_{2}-\mathrm{H}_{2}$ gas mixtures, containing 5, 24, and 76 vol.\% $\mathrm{N}_{2}$. Samples were characterized concerning the resulting roughness, microstructure, compound layer's phase composition, residual stresses in the diffusion zone, and surface hardness. Tribological ball-on-flat tests were carried out in reciprocal mode using zirconia as ball material for friction coefficient and the compound layer resistance until the first damage. The test results were evaluated statistically by analysis of variance (ANOVA). As the amount of nitrogen in the gas mixture decreases, the $\varepsilon-\mathrm{Fe}_{2-3}(\mathrm{C}) \mathrm{N}$ content in the compound layer decreases. A $\gamma^{\prime}-\mathrm{Fe}_{4} \mathrm{~N}$ monophasic compound layer was achieved at $5 \mathrm{vol} \% \mathrm{~N}_{2}$ gas mixture. The diffusion zone as expected presented compressive residual stresses with the highest values near the surface. In the tribological tests, better results were obtained for 5 and 24 vol. $\% \mathrm{~N}_{2}$ in the gas mixture as higher amounts of $\gamma^{\prime}-\mathrm{Fe}_{4} \mathrm{~N}$ were formed. The 76 vol. $\% \mathrm{~N}_{2}$ gas mixture led to a brittle behavior, due to the biphasic compound layer $\left(\gamma^{\prime}-\mathrm{Fe}_{4} \mathrm{~N}\right.$ and $\left.\varepsilon-\mathrm{Fe}_{2-3}(\mathrm{C}) \mathrm{N}\right)$ with a predominant content of $\varepsilon-\mathrm{Fe}_{2-3}(\mathrm{C}) \mathrm{N}$.

Keywords: Bainitic Steel, Plasma Nitriding, Gas Mixture Influence, Compound Layer, Tribological Characterization.

\section{Introduction}

Continuous cooling bainitic steels has an increasing use in industrial processes owing to its excellent combination of yield strength and toughness ${ }^{1-4}$. The new generation of continuous cooling bainitic steels allows the formation of different bainitic morphologies, such as granular bainite, degenerate upper bainite, and lower bainite, and may contain other phases such as retained austenite and ferrite ${ }^{5-9}$. Unlike quenched and tempered steels, which need further heat treating to obtain properties suitable for their applications ${ }^{10,11}$, continuous cooling bainitic steels already present high levels of strength and toughness after hot rolling or forging, presenting the potential to shorten processing routes ${ }^{5,6,8,12}$.

The surface properties of continuous cooling bainitic steels are acceptable for many purposes ${ }^{13-16}$, but surface hardness and wear resistance are insufficient for some highly loaded automotive components. Therefore, the development of surface treatments able to increase surface properties

*e-mail: rldalcin@gmail.com without losing core hardness in this type of steel is essential to achieve application requirements. The effect of tempering on the microstructure and mechanical properties of a nonquenched (NQ) bainitic steel was investigated by Luo et al. ${ }^{1}$. The results show that the NQ steel without tempering is about $37 \mathrm{HRC}$, and changes little after tempering between $300{ }^{\circ} \mathrm{C}$ and $550{ }^{\circ} \mathrm{C}$, while it decreases sharply at $600{ }^{\circ} \mathrm{C}$, and reaches $30 \mathrm{HRC}$. Therefore, the effect of these temperaturetime cycles on the microstructure of bainitic steels must be controlled, since it changes the mechanical properties significantly as described in Luo et al. ${ }^{1}$. In this sense, plasma nitriding can be an adequate choice. Nevertheless, in the literature, investigations on tribological tests of plasma nitrided continuous cooling bainitic steels are still very scarce.

In general, the plasma nitriding process promotes metallurgical chemical reactions on the surface of treated steels, leading to compound layer formation, consisting of $\varepsilon-\mathrm{Fe}_{2-3} \mathrm{~N}$ and $\gamma^{\prime}-\mathrm{Fe}_{4} \mathrm{~N}$ nitrides ${ }^{17,18}$. The microstructure of the compound layer and of the diffusion zone, as well as the combination with the steel core properties are designed to 
accomplish with the desired final properties ${ }^{19-21}$. In previous articles the authors investigated the microstructure and residual stresses of plasma nitrided DIN 18MnCrSiMo6-4 continuous cooling bainitic steel ${ }^{22,23}$, which showed excellent results concerning case depth, surface hardness, and compressive residual stresses in the diffusion zone. The influence of different plasma nitriding temperatures on the surface modifications and reciprocating dry sliding wear properties of the continuous cooling bainitic steel was investigated ${ }^{21}$. The purpose of the present article is to discuss, for the first time, the influence of different plasma nitriding gas mixtures on the surface modifications and the compound layer resistance until the first damage (microcracks formation or delamination of the surface layer) on reciprocating dry sliding of the continuous cooling bainitic steel. The importance of studying the influence of different nitrogen composition in the gas mixture is due to the variation of $\mathrm{Fe}_{2-3} \mathrm{~N}$ and $\gamma^{\prime}-\mathrm{Fe}_{4} \mathrm{~N}$ formed in the compound layer, and these, in turn, have a direct influence in the first damage resistance.

\section{Materials and Methods}

The steel to be plasma nitrided was a DIN 18MnCrSiMo6-4 steel which is a continuous cooling bainitic steel. The material's microstructure obtained directly after hot rolling and controlled cooling is composed of pro-eutectoid ferrite and granular bainite ${ }^{7,8,22}$. The material's chemical composition and mechanical properties are given in Table 1. The surface treatment was carried out in a plasma nitriding furnace equipped with a direct current (DC) power supply $(120 \mathrm{~Hz})$. A simple scheme of the system showing how the samples and thermocouple were positioned is presented in Figure 1.

Prior to the surface treatments, samples flat faces were ground with silicon carbide grinding paper in a sequence with increasing grit sizes (\#100, \#220, \#320, \#400, \#600, \#1200) and then polished with $3 \mu \mathrm{m}$ diamond wax paste. The samples were degreased and cleaned with acetone in an ultrasonic bath before being placed into the plasma nitriding furnace. A sputtering step was performed for $15 \mathrm{~min}$, using pure hydrogen with a flow of $140 \mathrm{sccm}$. In the heating stage, until reaching the treatment temperature, it was used a gas mixture composed of argon and hydrogen, with $150 \mathrm{sccm}$ of argon and $140 \mathrm{sccm}$ of $\mathrm{H}_{2}$. Nitriding treatments were conducted at $500{ }^{\circ} \mathrm{C}$ with three sets of gas mixtures compositions (5, 24 , and 76 vol. $\left.\% \mathrm{~N}_{2}\right)$, and times of $(3,6$, and $9 \mathrm{~h}$ ). Table 2 summarizes the different plasma nitriding runs.

Voltage as well pressure is adjusted to reach the treatment temperature. Since the chamber worked in cold wall mode, i.e., no auxiliary heating system was used, the heating of samples was directly dependent on the ion bombardment. Plasma nitriding treatments carried in an atmosphere containing more hydrogen, requires applications of greater potential differences, since hydrogen atom mass is lower causing a small linear moment than nitrogen ${ }^{24}$. Consequently, the pressure must be adjusted for compensation, leading to the need of a higher pressure in the treatments with the gas

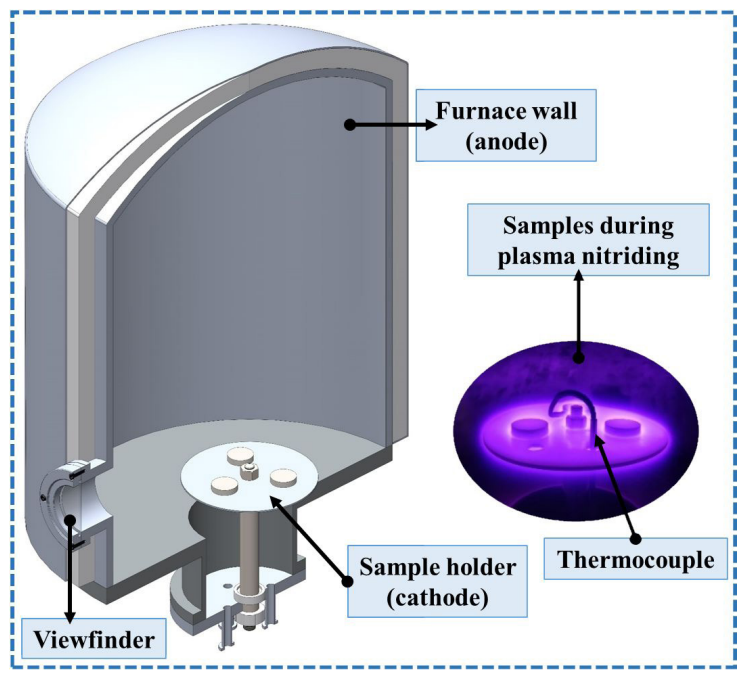

Figure 1. Simple scheme of the system showing how the samples and thermocouple were positioned.

Table 1. Chemical composition and mechanical properties of the DIN 18MnCrSiMo6-4 steel.

\begin{tabular}{|c|c|c|c|c|c|c|c|c|c|}
\hline \multicolumn{10}{|c|}{ Chemical elements (wt.-\%) } \\
\hline $\mathbf{C}$ & Mn & Si & $\mathrm{Cr}$ & Mo & $\mathbf{N i}$ & Al & $\mathbf{P}$ & $\mathbf{S}$ & $\mathrm{Fe}$ \\
\hline 0.19 & 1.35 & 1.16 & 1.14 & 0.26 & 0.06 & 0.01 & 0.01 & 0.01 & Balance \\
\hline \multicolumn{10}{|c|}{ Mechanical properties (average values) } \\
\hline \multicolumn{2}{|c|}{ Yield stress (MPa) } & \multicolumn{3}{|c|}{ Tensile strength (MPa) } & \multicolumn{2}{|c|}{ elongation (\%) } & \multicolumn{3}{|c|}{ Hardness $\left(\mathrm{HV}_{0.1}\right)$} \\
\hline \multicolumn{2}{|c|}{$825 \pm 18$} & \multicolumn{3}{|c|}{$1017 \pm 31$} & \multicolumn{2}{|c|}{$17 \pm 1$} & \multicolumn{3}{|c|}{$330 \pm 12$} \\
\hline
\end{tabular}

Table 2. Parameters used for plasma nitriding of samples using three different nitrogen gas composition.

\begin{tabular}{|c|c|c|c|c|}
\hline Nitriding time (h) & Temperature $\left({ }^{\circ} \mathrm{C}\right)$ & Gas mixture (vol. $\% \mathrm{~N}_{2}$ in $\left.\mathrm{H}_{2}\right)$ & Current density $\left(\mathrm{mA} / \mathrm{cm}^{2}\right)$ & Chamber pressure $(\mathrm{Pa})$ \\
\hline 3 & \multirow{3}{*}{$500 \pm 2$} & \multirow{3}{*}{5 vol. $\% \mathrm{~N}_{2}$ in 95 vol. $\% \mathrm{H}_{2}$} & \multirow{3}{*}{$1.8 \pm 0.21$} & \multirow{3}{*}{$400 \pm 3$} \\
\hline 6 & & & & \\
\hline 9 & & & & \\
\hline 3 & \multirow{3}{*}{$500 \pm 2$} & \multirow{3}{*}{24 vol. $\% \mathrm{~N}_{2}$ in 76 vol. $\% \mathrm{H}_{2}$} & \multirow{3}{*}{$2.1 \pm 0.21$} & \multirow{3}{*}{$300 \pm 3$} \\
\hline 6 & & & & \\
\hline 9 & & & & \\
\hline 3 & \multirow{3}{*}{$500 \pm 2$} & \multirow{3}{*}{76 vol. $\% \mathrm{~N}_{2}$ in 24 vol. $\% \mathrm{H}_{2}$} & \multirow{3}{*}{$2.4 \pm 0.10$} & \multirow{3}{*}{$300 \pm 3$} \\
\hline 6 & & & & \\
\hline 9 & & & & \\
\hline
\end{tabular}


mixture 5 vol. $\% \mathrm{~N}_{2}\left(95\right.$ vol. $\left.\% \mathrm{H}_{2}\right)$ than for the other gas compositions. The current density was calculated by dividing the measured current by the total area covered by the plasma sheath. The current density cannot be directly controlled, as an auxiliary heating system was not used. The temperature depends on the current density. The current density depends on the voltage, pressure and gas composition ${ }^{21}$.

For the microstructural analysis of the nitrided layers, samples were carefully cut perpendicular to the upper nitrided face in a precision diamond blade cutting machine. After hot pressing mounting in bakelite, the cross-sections were ground with silicon carbide grinding papers in a sequence with increasing grit sizes (\#100, \#220, \#320, \#400, \#600, $\# 1200$ ) and polished with a diamond paste of $3 \mu \mathrm{m}$ particle size. A Nital 3\% solution was used to etch the samples revealing the microstructure of the nitrided layers. The cross-sectional microstructural images were obtained by an Olympus metallurgical microscope (BX51M model). The compound layer thickness was measured using the Image- $J$ software.

X-ray diffraction for phase analysis were carried out using a XRD $M$-Research Edition diffractometer (GE Seifert Charon model) equipped with a Meteor $1 D$ fast line position sensitive detector with $20^{\circ} \mathrm{C}$ window. Phase analysis was performed on samples surface in the Bragg-Brentano geometry $(\theta-2 \theta)$ with $\mathrm{Cr}-\mathrm{K} \alpha(\lambda=2.2897 \AA)$ radiation. Diffraction lines were recorded in the range of $2 \theta$ from $55^{\circ}$ to $80^{\circ}$, with a step size of $0.01^{\circ}$ and a scan time of $200 \mathrm{~s}$ per step. The present phases in the materials were determined by comparison with the standards contained in the crystallographic information files (CIFs) from the Crystallography Open Database ${ }^{25}$ and the Inorganic Crystal Structures Database ${ }^{26}$ by analysis in the Profex-BGMN software ${ }^{27}$.

Residual stresses were determined by X-ray diffraction in the same equipment at three different positions on the sample's faces by using a $\psi$-diffractometer with $\mathrm{Cr}-\mathrm{K} \alpha$ radiation. For strain determination, the $\{211\}$ diffraction lines of $\alpha$-iron were recorded at $15 \psi$ inclinations in the range of $-60^{\circ}$ to $+60^{\circ}$. The $\sin 2 \psi$ method with macroscopic elastic constants of steel, $\mathrm{E}=210 \mathrm{GPa}$ and $v=0.28$, was used for residual stress calculations. The penetration depth of $\mathrm{Cr}-\mathrm{K} \alpha$ radiation in the $\alpha$-iron allowed measurements in the diffusion zone, even with a small layer at the surface ${ }^{17}$. To obtain the residual stress profiles of the samples, successive layer removals were carried out by an electro etching device. During the layer removal process, the samples were dipped into a solution containing $24.19 \%$ distilled water, $33.87 \%$ sulfuric acid $\left(\mathrm{H}_{2} \mathrm{SO}_{4}\right)$, and $41.94 \%$ phosphoric acid $\left(\mathrm{H}_{3} \mathrm{PO}_{4}\right)$. A magnetic stirrer was used to mix the solution during the whole process. The sample was connected to the anode and the stainless steel container, which held the electrolytic solution, was connected to the cathode. A voltage of $10 \mathrm{~V}$ was applied resulting in a current of about $10 \mathrm{~A}$ during the removal process. The sample thickness was measured before and after a pre-set attack time using a micrometer. The estimated depth measurement error was $\pm 1 \mu \mathrm{m}$. About eight removals with successive measurements were carried out for each sample.

Vickers microhardness tests were applied to the plasma nitrided samples for determination on the surface hardness and Vickers microhardness profiles of the cross-sections. In the tests, an Insize microhardness tester (ISH-TDV 1000 model) was used. Five microhardness profiles per sample were constructed by Vickers microhardness testing, using a load of $100 \mathrm{gf}$ with a dwell time of $10 \mathrm{~s}^{28}$. The case depth (compound layer + diffusion zone) was conventionally determined by the distance from the surface where core hardness is exceeded in $50 \mathrm{HV}^{21}$. The determination of the case depth was carried out based on the microhardness profiles and following the recommendations established in DIN $50190^{29}$.

To evaluate the surface hardness for plasma nitrided samples the instrumented hardness technique was used with a Shimadzu ultramicrodurometer ( $D U H-211 S$ model), equipped with a Berkovich indenter. The measurements were done for the plasma nitrided samples and the results are an average of 5 indentations with a maximum applied load of $1000 \mathrm{mN}$ during $10 \mathrm{~s}$.

The roughness parameters $\left(\mathrm{R}_{\mathrm{a}}\right.$ and $\left.\mathrm{R}_{\mathrm{z}}\right)$ were measured with a Mitutoyo contact profilometer ( $S J-210$ model) equipped with an $8 \mu \mathrm{m}$ tip radius probe, based on ISO $4287^{30}$. Due to the topographic characteristics of the samples, measurements were made using the aperiodic roughness profiles configuration ${ }^{31}$. A cutoff of $0.8 \mathrm{~mm}$ and a measurement length of $4.0 \mathrm{~mm}$ were set on the profilometer.

Wear tests (three repetitions for each condition) were carried out under dry conditions, using a CETR UMT (Universal Material Tester) tribometer with a reciprocating ball-on-flat configuration, according to the standard ASTM $\mathrm{G} 133^{32}$, for measurements of friction coefficient and the first damage resistance. The surfaces were placed in contact against a zirconia ball $\left(1150 \mathrm{HV}_{0.1} \pm 28\right)$ with a diameter of $4.76 \mathrm{~mm}$. The choice of a ball with a close hardness to the nitrided surface is due to the need to simulate the contact conditions with a close hardness, such as for example, the contact between the flanks of the gears, to be tested in future works. The load of $6 \mathrm{~N}$ was applied to press a zirconia ball (maximum contact pressure nearly $1351 \mathrm{MPa}$ ) against the surface of the plasma nitrided samples. Sliding proceeded in the reciprocating mode over a $4 \mathrm{~mm}$ long track at a frequency of $4 \mathrm{~Hz}$. The tests were stopped after a given damage criteria involving the rapid growth of the friction coefficients and the first damage resistance. The wear mechanisms were identified in a Zeiss scanning electron microscope (EVO MA 15 model).

Interaction plots for case depth, surface hardness, and sliding distance before the time of microcracks formation or delamination of the surface layer, with nitrogen gas composition and nitriding time were generated. The data was then submitted to an analysis of variance, in order to evaluate the statistical significance of nitrogen gas composition variation and treatment time on the first damage resistance, following the Tukey's-b post hoc test ${ }^{33}$ by using the statistical package program (Minitab 16). Three repetitions and a confidence level of $95 \%$ (significance level $\alpha=0.05$ ) were used.

\section{Results and Discussion}

As a representative result of the plasma nitriding treatments, the cross-sectional microstructure of plasma nitrided sample for $9 \mathrm{~h}$, using 24 vol. $\% \mathrm{~N}_{2}$ is presented in 
Figure $2 \mathrm{a}$. Figure $2 \mathrm{~b}$ show that longer nitriding times and nitrogen richer gas composition led to greater diffusion zones and thicker compound layers. When comparisons are done between these three nitriding conditions, 5, 24, and 76 vol.\% $\mathrm{N}_{2}$, in terms of case depth, the behavior is as expected, the higher the $\mathrm{N}_{2}$ content in the gas mixture increase the total case depth. However, for the gas composition of 5 vol. $\% \mathrm{~N}_{2}$, the plasma nitrided layer is predominantly composed by a diffusion zone whereas for 24 and 76 vol. $\% \mathrm{~N}_{2}$ a compound layer is clearly seen.

All the plasma nitrided samples showed diffraction peaks that indicate the formation of a compound layer ${ }^{22,23}$. Figures $3 \mathrm{a}-\mathrm{c}$ also show the formation of a biphasic compound layer $\left(\varepsilon-\mathrm{Fe}_{2-3}(\mathrm{C}) \mathrm{N}\right.$ and $\left.\gamma^{\prime}-\mathrm{Fe}_{4} \mathrm{~N}\right)$ on the plasma nitrided samples with 24 and 76 vol. $\% \mathrm{~N}_{2}$, while the plasma nitrided samples with 5 vol. $\% \mathrm{~N}_{2}$ indicated a monophasic compound layer $\left(\gamma^{\prime}-\mathrm{Fe}_{4} \mathrm{~N}\right)$. Normally, a $\varepsilon-\mathrm{Fe}_{2-3}(\mathrm{C}) \mathrm{N}$ compound layer would be expected to be harder than a $\gamma^{\prime}-\mathrm{Fe}_{4} \mathrm{~N}$ layer on the plasma nitrided samples. Since the penetration depth increases with $2 \theta$ angle ${ }^{34,35}$, the peaks of the $\varepsilon-\mathrm{Fe}_{2-3}(\mathrm{C}) \mathrm{N}$ phase, contained in the compound layer, are more easily identified with smaller $2 \theta$ angles. Diffractograms of non-nitrided samples shows the $\alpha$-Iron peaks, from the ferritic phases. The intensity of the peaks of the $\alpha$-Iron and the retained austenite decreases with the increase of the compound layer thickness, as the opposite takes place with $\varepsilon-\mathrm{Fe}_{2-3}(\mathrm{C}) \mathrm{N}$ and $\gamma^{\prime}-\mathrm{Fe}_{4} \mathrm{~N}$ phase peaks, because to the absorption of the radiation by the most superficial portions of the material ${ }^{21}$. In general, the intensity of the peaks related to the $\gamma^{\prime}-\mathrm{Fe}_{4} \mathrm{~N}$ and $\varepsilon-\mathrm{Fe}_{2-3}(\mathrm{C})$ $\mathrm{N}$ nitrides increases with the nitrogen gas composition and treatment time, since compound layer thickness follow the increase of these parameters, Figure $2 b$.

Figures $4 \mathrm{a}-\mathrm{c}$ show the residual stress profiles and Figures $4 \mathrm{~d}-\mathrm{f}$ the microhardness profiles of the plasma nitrided samples for all the treatment times and gas mixtures. An abrupt drop in hardness values corresponded to an abrupt decrease in compressive residual stresses. Similarly, when the drop in hardness was gradual, the reduction in compressive residual stresses was gradual. It is also noteworthy that the residual stresses profiles become tensile in the vicinity

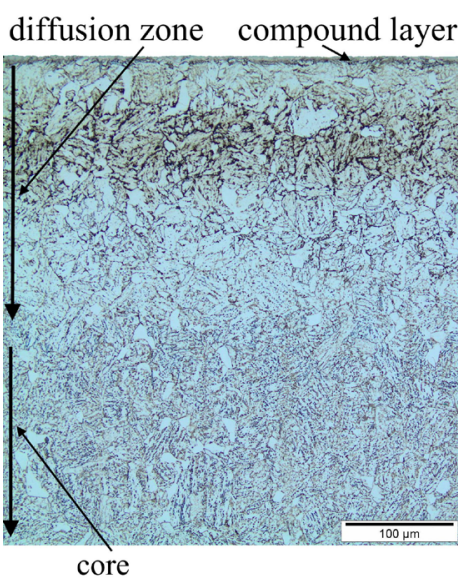

(a)

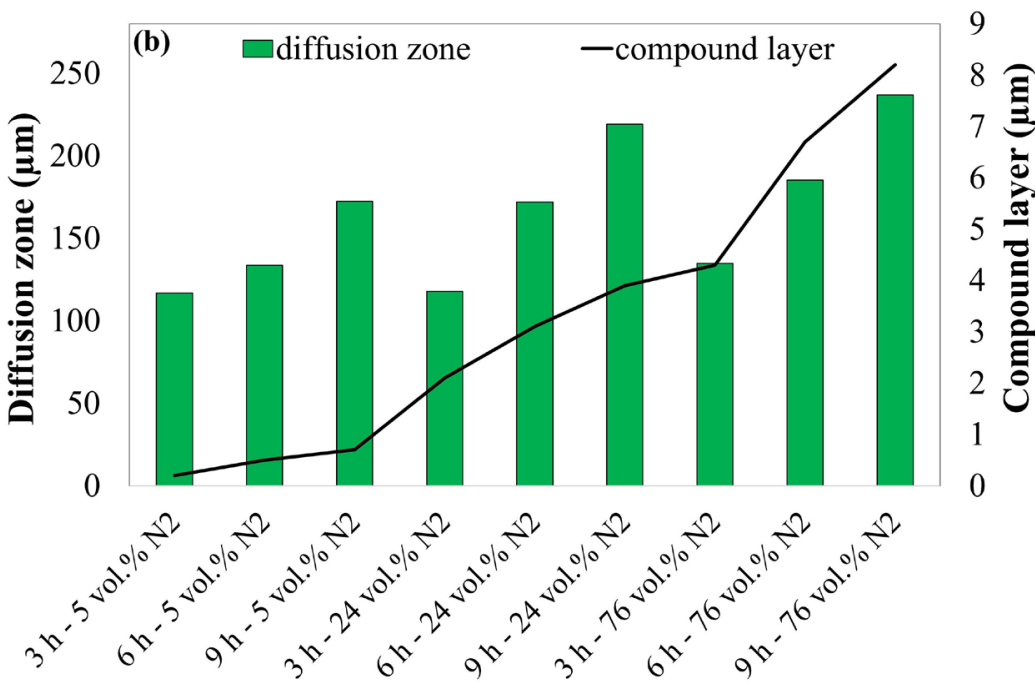

Figure 2. (a) Optical microstructure of cross-section of plasma nitrided samples for $9 \mathrm{~h}$ with gas mixture composition of 24 vol. $\% \mathrm{~N}_{2}$; (b) Diffusion zone and compound layer of plasma nitrided samples.
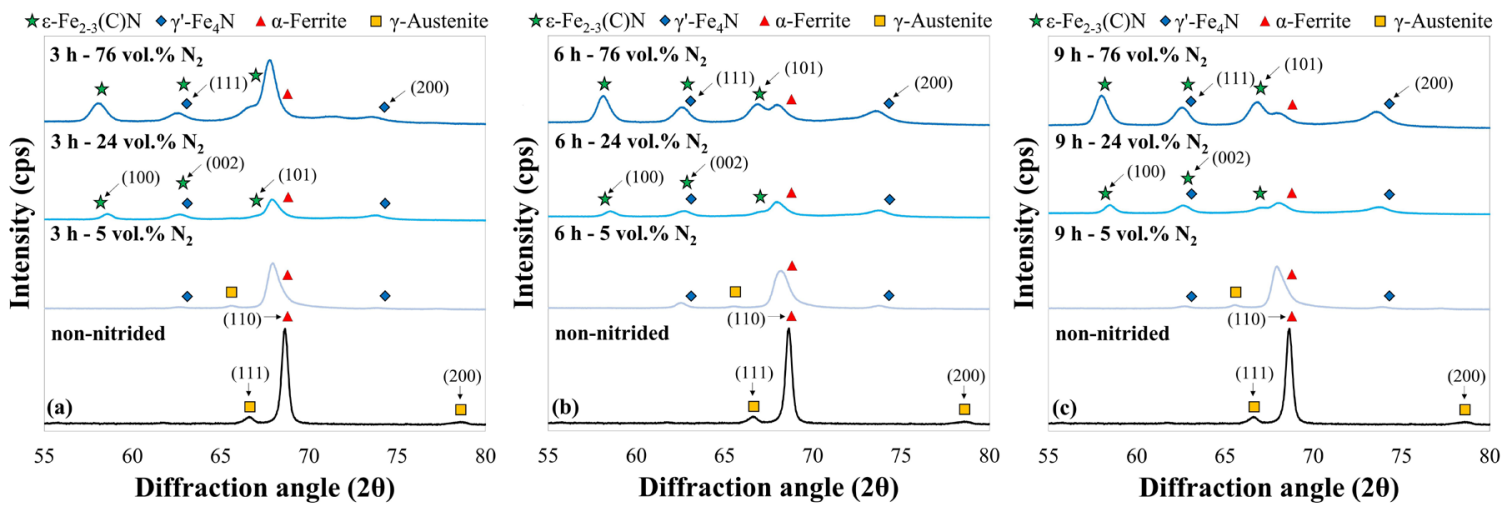

Figure 3. X-ray diffraction patterns of non-nitrided and plasma nitrided samples, with the indicated gas compositions $\left(5,24\right.$, and 76 vol. $\left.\% \mathrm{~N}_{2}\right)$ for (a) $3 \mathrm{~h}$, (b) $6 \mathrm{~h}$, and (c) $9 \mathrm{~h}$. 

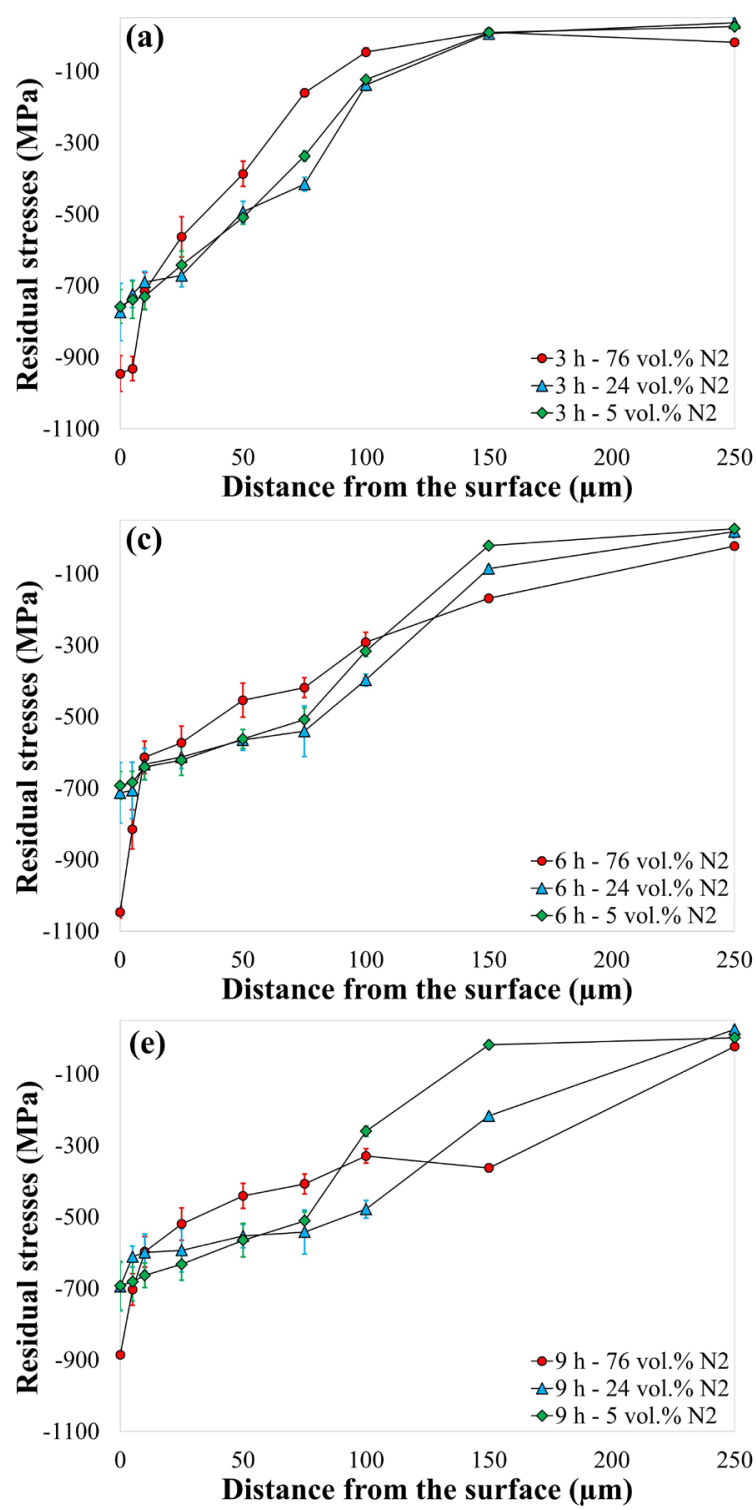
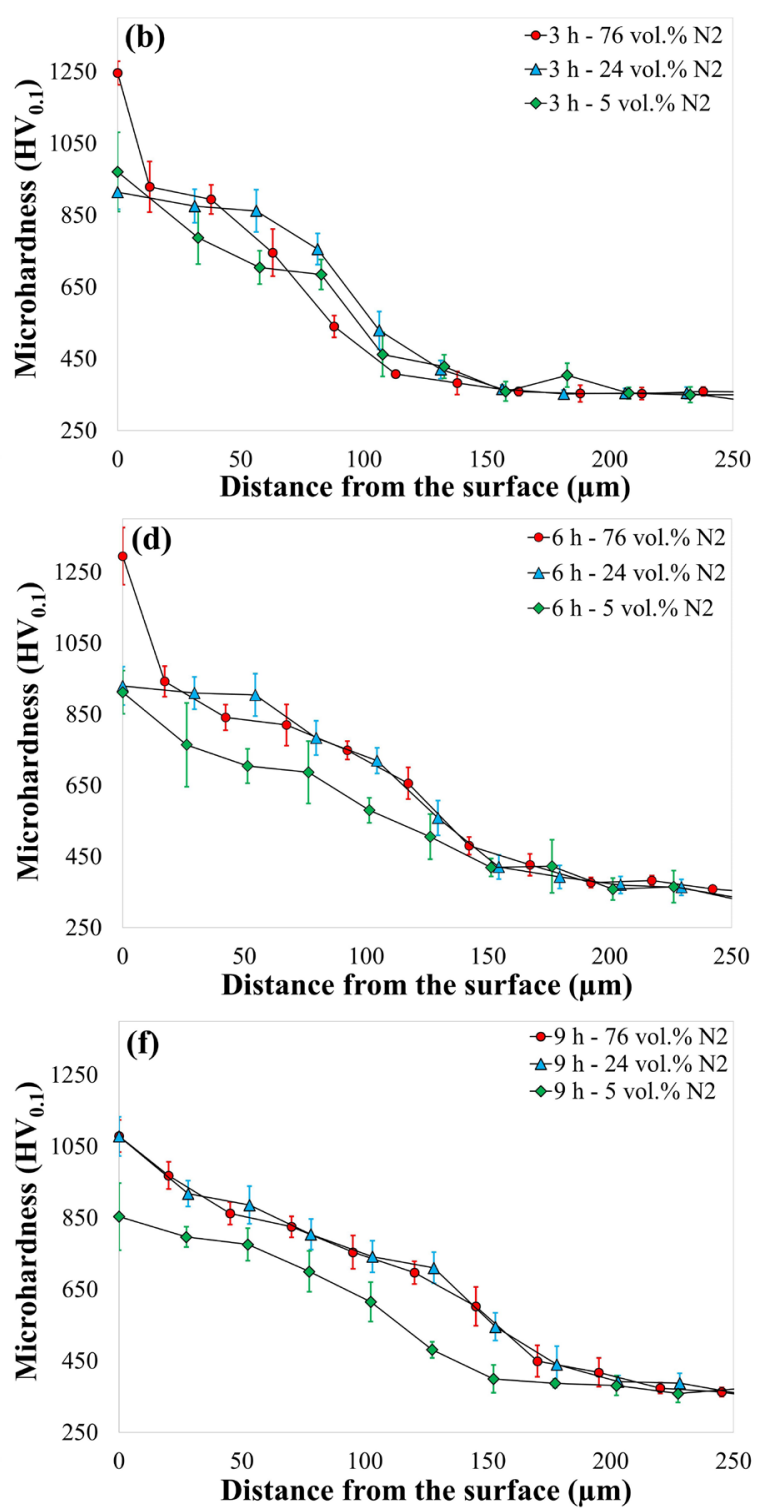

Figure 4. (a, b, c) Residual stresses profiles and (d, e, f) microhardness profiles of plasma nitrided samples with gas compositions of 5 , 24 , and 76 vol. $\% \mathrm{~N}_{2}$ for 3,6 , and $9 \mathrm{~h}$.

of the case/core interface, as already observed by other researchers ${ }^{18,22,23,36,37}$. Compressive residual stresses found in the diffusion zone are the result of structural misfits caused by the precipitation of alloy nitrides and carbonitrides in the iron matrix ${ }^{17}$, and also due to the saturation of the iron network with interstitial nitrogen.

In the case of plasma nitriding with nitrogen rich gas composition ( 76 vol. $\% \mathrm{~N}_{2}$ ), maximum compressive residual stresses of 885-1047 MPa were measured on the surface, depending on the treatment time. Decreasing the nitrogen gas mixture to an intermediate level $\left(24\right.$ vol. $\left.\% \mathrm{~N}_{2}\right)$ led to lower compressive residual stresses at the surface, resulting in compressive residual stress maximum in the range of 694-773 MPa. The same is true for plasma nitriding with a low amount of 5 vol. $\% \mathrm{~N}_{2}$, where depending on the nitriding time maximum compressive residual stresses in the range of 692 to $758 \mathrm{MPa}$ are measured on the surface. As in the case of nitriding time, an increase in nitrogen content in the gas composition results in higher compressive residual stresses in the surface ${ }^{23}$.

The microhardness value indicated at the zero distance from the surface, was not from the cross-section but from an indentation perpendicular to the surface instead. From the microhardness profiles, a case depth was estimated, Figure $2 b$. As expected, the hardness decreases from surface to core, since the concentration of metal nitrides decreases towards core $^{24}$. The plasma nitriding (greater surface hardness among the investigated group) increased the surface hardness by about $392 \%\left(1295 \mathrm{HV}_{01}\right)$ for plasma nitrided samples for $6 \mathrm{~h}$ with $76 \mathrm{vol} . \% \mathrm{~N}_{2}, 327 \%\left(1078 \mathrm{HV}_{01}\right)$ for plasma nitrided for $9 \mathrm{~h}$ with 24 vol. $\% \mathrm{~N}_{2}$, and up to $294 \%\left(970 \mathrm{HV}_{0.1}\right)$ for plasma nitrided samples for $3 \mathrm{~h}$ with $5 \mathrm{vol} . \% \mathrm{~N}_{2}$. It can be seen in 
Figures $3 d-f$ that the hardness of the diffusion zone increases with the treatment time, as shown by Dalcin et al. ${ }^{21,23}$ and Lee and Park $^{38}$. The mechanical properties of the diffusion zone influence the fracture properties of the compound layer since it provides support for the surface ${ }^{22,23,39}$. Dalcin et al. ${ }^{23}$ showed that the nitrogen rich gas composition promoted a decrease in the fracture toughness of the compound layer.

The hardness measured on the plasma nitrided surfaces with a load of $1000 \mathrm{mN}$ has been show in Figure 5, using the instrumented hardness technique with a Berkovich indenter. Plasma nitriding significantly increased the hardness of plasma nitrided surfaces, as expected, see Figure 5. The plasma nitrided samples in the gas composition with the highest nitrogen concentration $\left(76 \mathrm{vol} . \% \mathrm{~N}_{2}\right)$ tend to show a more pronounced increase in surface hardness when compared to the other groups of plasma nitrided samples (24 and 5 vol.\% $\mathrm{N}_{2}$ ), as seen in Vickers microhardness measurements. The treatments with higher nitrogen content in the gas composition ( 76 vol. $\% \mathrm{~N}_{2}$ ) promote an increase in surface hardness due to the increase in the $\varepsilon-\mathrm{Fe}_{2-3}(\mathrm{C}) \mathrm{N}$ phase in the compound layer, Figures 3a-c. Despite the plasma nitrided samples with 24 vol. $\% \mathrm{~N}_{2}$ having biphasic compound layers $\left(\varepsilon-\mathrm{Fe}_{2-3}(\mathrm{C})\right.$ $\mathrm{N}$ and $\gamma^{\prime}-\mathrm{Fe}_{4} \mathrm{~N}$ ), Figures $3 \mathrm{a}-\mathrm{c}$, did not present significant dispersion in the hardness between the nitriding times, as well as in the plasma nitrided samples with 5 vol. $\% \mathrm{~N}_{2}$, which have monophasic $\left(\gamma^{\prime}-\mathrm{Fe}_{4} \mathrm{~N}\right)$ compound layers, Figures $3 \mathrm{a}-\mathrm{c}$.
The greater dispersion between the hardness of the plasma nitrided samples with nitrogen rich gas compositions (76 vol.\% $\mathrm{N}_{2}$ ) can be associated to the presence of the $\varepsilon-\mathrm{Fe}_{2-3}(\mathrm{C}) \mathrm{N}$ and $\gamma^{\prime}-\mathrm{Fe}_{4} \mathrm{~N}$ phases, which present different mechanical behavior (hardness and wear resistance).

To investigate the influence of nitriding time and nitrogen gas composition on the surface topography, the roughness values (parameters $R_{a}$ and $R_{z}$ ) measured before and after plasma nitriding are shown in Figures $6 \mathrm{a}, 6 \mathrm{~b}$. In the cases shown in Figures $6 \mathrm{a}, 6 \mathrm{~b}$, the exposure time to ion bombardment ends up changing the roughness final a lot, confirming the results reported by Sun et al. ${ }^{40}$ and Lampe et al. ${ }^{41}$. This generalized increase in roughness after nitriding $\left(R_{a}\right.$ and $R_{z}$ parameter) can be related to the ion bombardment during plasma nitriding treatment and the formation mechanism of the nitrided layer ${ }^{40-42}$.

The friction coefficients (COF) obtained on the wear tests are shown in Figures 7a-c. Regardless of the nitrogen gas composition $\left(5,24\right.$, and 76 vol. $\left.\% \mathrm{~N}_{2}\right)$, at the beginning of the reciprocal sliding wear test, the behavior of the plasma nitrided samples is similar between the same treatment times (from point of view of the COF). The COF is higher even with the roughness being lower in non-nitrided samples and in the plasma nitrided samples for $3 \mathrm{~h}$. Probably, the lower compound layer thickness of the plasma nitrided samples for $3 \mathrm{~h}$ contributed to the more accentuated wear in the

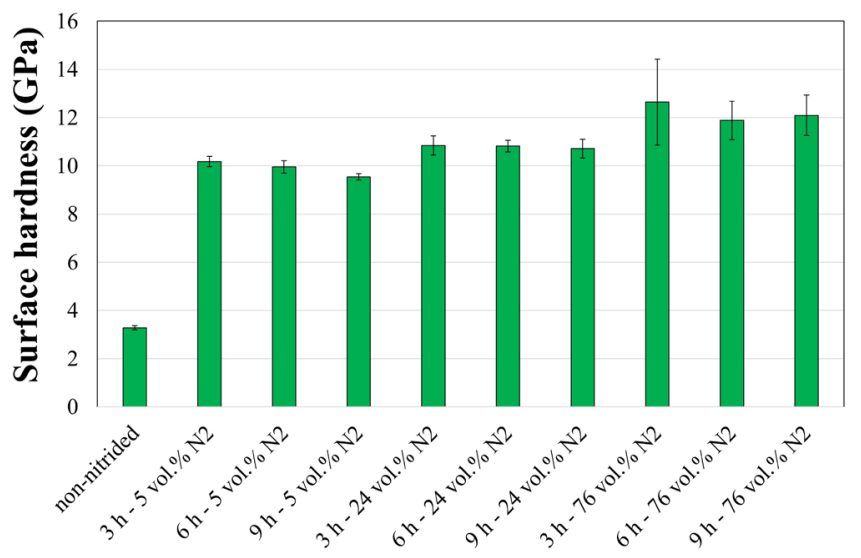

Figure 5. Surface hardness of non-nitrided and plasma nitrided samples.
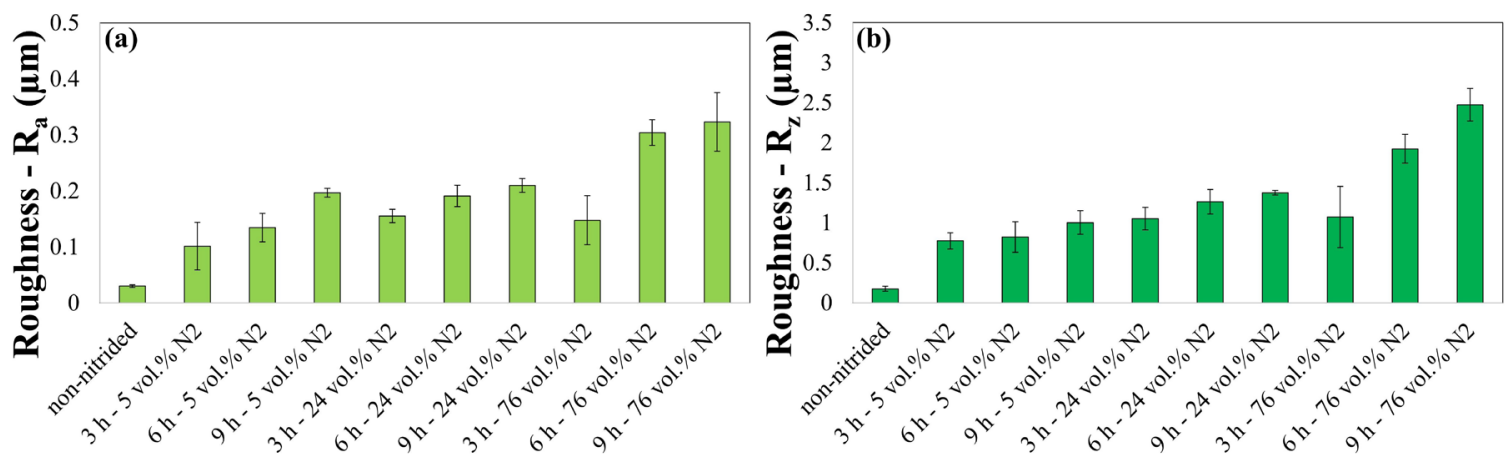

Figure 6. Roughness measurements in the non-nitrided samples and plasma nitrided samples with gas mixture composition of 76, 24, and 5 vol. $\% \mathrm{~N}_{2}$ : (a) $\mathrm{R}_{\mathrm{a}}$; (b) $\mathrm{R}_{\mathrm{z}}$. 

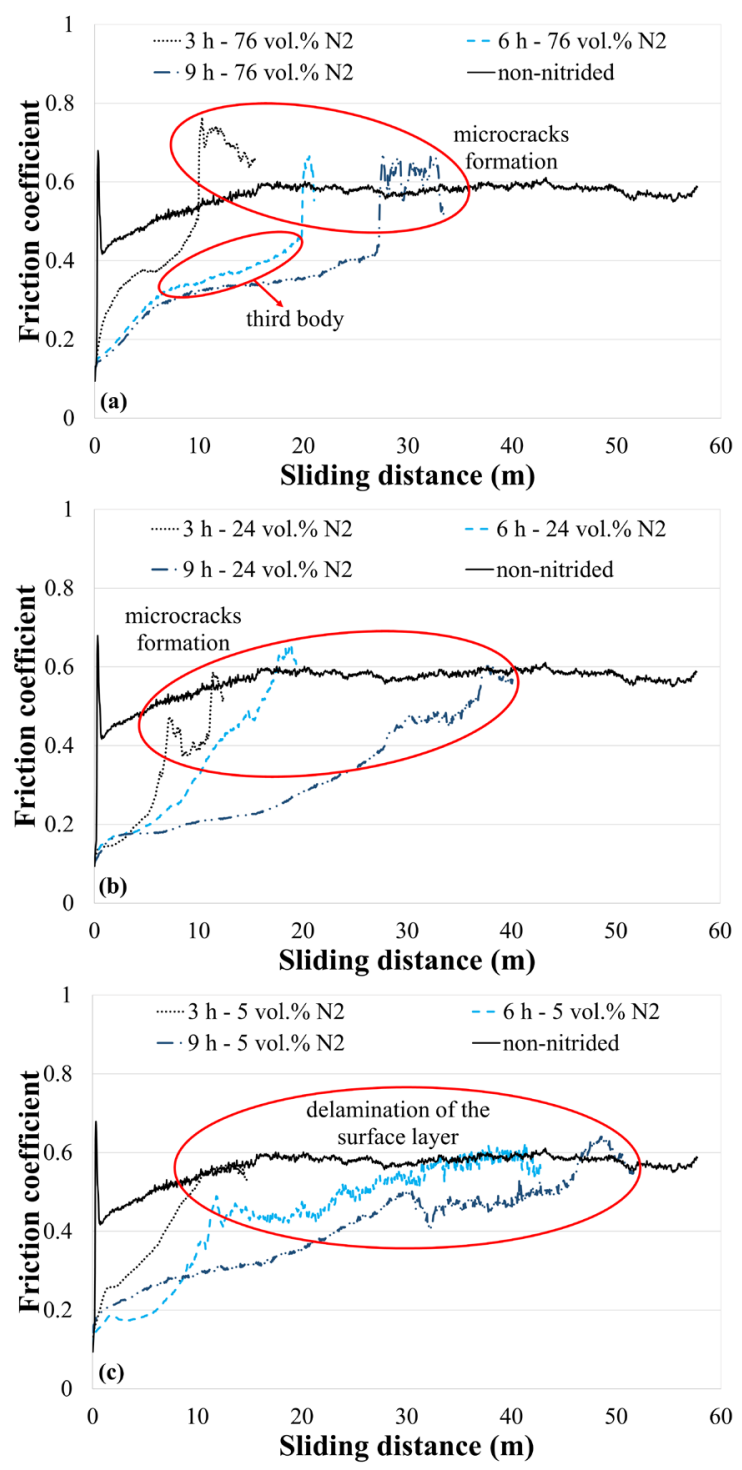

Figure 7. Friction coefficient obtained in reciprocating dry sliding wear tests on non-nitrided and plasma nitrided samples for with gas mixture composition of (a) $76 \mathrm{vol} . \% \mathrm{~N}_{2}$, (b) 24 vol. $\% \mathrm{~N}_{2}$, and (c) 5 vol. $\% \mathrm{~N}_{2}$. first meters of sliding distance, Figures 7a-c and Figure 8, while the non-nitrided samples wear more quickly due to the lower surface hardness. In the beginning phase of the wear test (between 0 and $1 \mathrm{~m}$ ) the COF of the non-nitrided samples showed a peak with values higher than the steadystate due to the beginning breakdown of the topography peaks and valleys.

The average $\mathrm{COF}$ of the non-nitrided samples was $0.56 \pm 0.05$ (admitting that the steady-state occurs from $30 \mathrm{~m}$ ). The results show that the nitriding treatments were responsible for the reduction of the COF, Figures $7 \mathrm{a}-\mathrm{c}$. The relative movement between the ball and the sample causes wear on the surface of the sample and the ball. The variation of the track topography (increased roughness, third-body particles of the sample material and the ball, among others), increases the difficulty in sliding between the ball and the surface of the material, causing an increase in COF. The lower COF at first occurs due to the ceramic characteristics of the compound layer ${ }^{43,44}$. The increase in $\mathrm{COF}$, over time of wear is due to the presence of the third body of the ball and of the compound layer that was wearing out, see Figures $7 \mathrm{a}-\mathrm{c}$. The sudden growth of COF, represents the microcracks in the compound layer ${ }^{45}$, typical for brittle materials. The propagation of these microcracks results in delamination of the surface layer ${ }^{46}$, as illustrated by Figures 9a, 9b, Figures 10a, 10b and Figures 11a, $11 \mathrm{~b}$.

In the plasma nitrided samples with 76 vol. $\% \mathrm{~N}_{2}$, Figure $7 \mathrm{a}$, after the third body formation phase and increased wear, there was an abrupt increase in COF, up to levels higher than the non-nitrided samples. In these cases, the abrupt rupture of the compound layer is associated with greater brittleness of the biphasic phases $\left(\varepsilon-\mathrm{Fe}_{2-3}(\mathrm{C}) \mathrm{N}\right.$ and $\left.\gamma^{\prime}-\mathrm{Fe}_{4} \mathrm{~N}\right)$ and causes the formation of microcracks and delamination of the surface layer, Figures 11a, 11b. The plasma nitrided samples with 5 and 24 vol. $\% \mathrm{~N}_{2}$, Figures $7 \mathrm{~b}, 7 \mathrm{c}$, did not present an abrupt rupture of the compound layer as found in the samples with greater surface hardness $\left(76 \mathrm{vol} . \% \mathrm{~N}_{2}\right)$. After the third body formation phase, there was an inhomogeneous behavior for a certain time (between 10 and $40 \mathrm{~m}$ ). Probably in this phase, the propagation of cracks promoted the beginning of the delamination of the superficial layer and increased the intensity with the course of the test. When the COF reached

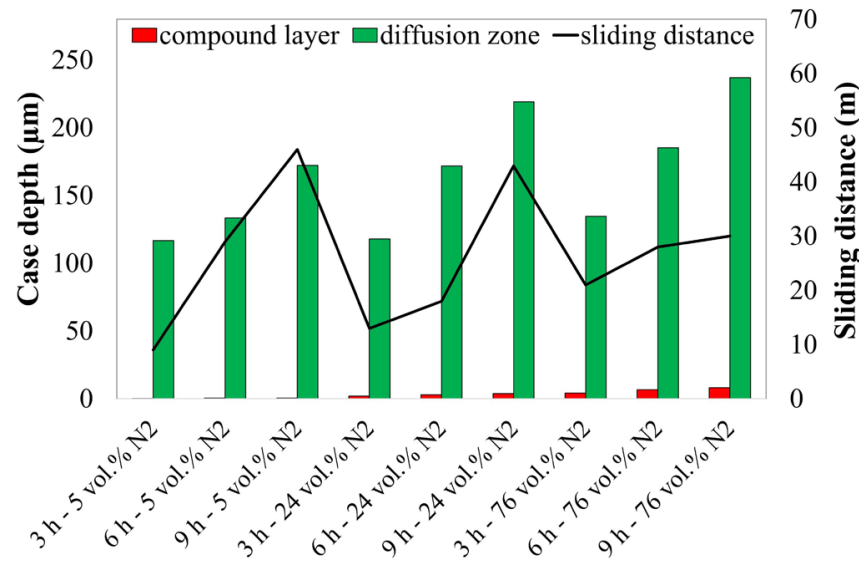

Figure 8. Compilation of results from case depth and sliding distance before microcracks formation or delamination of the surface layer. 


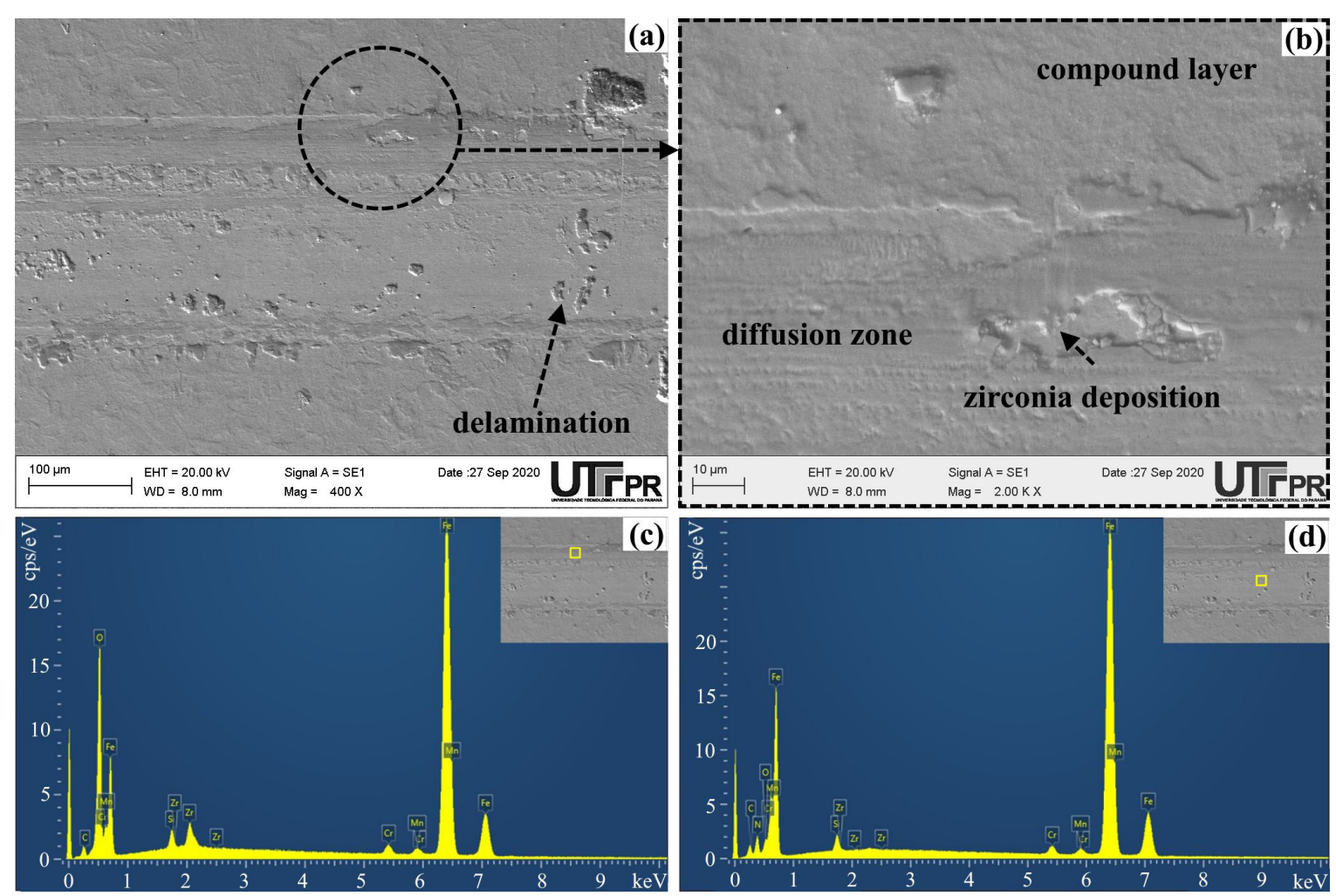

Figure 9. (a, b) SEM images and (c, d) EDS analysis of the wear tracks after reciprocal sliding wear of plasma nitrided samples for $9 \mathrm{~h}$ with gas mixture composition of 5 vol. $\% \mathrm{~N}_{2}$.

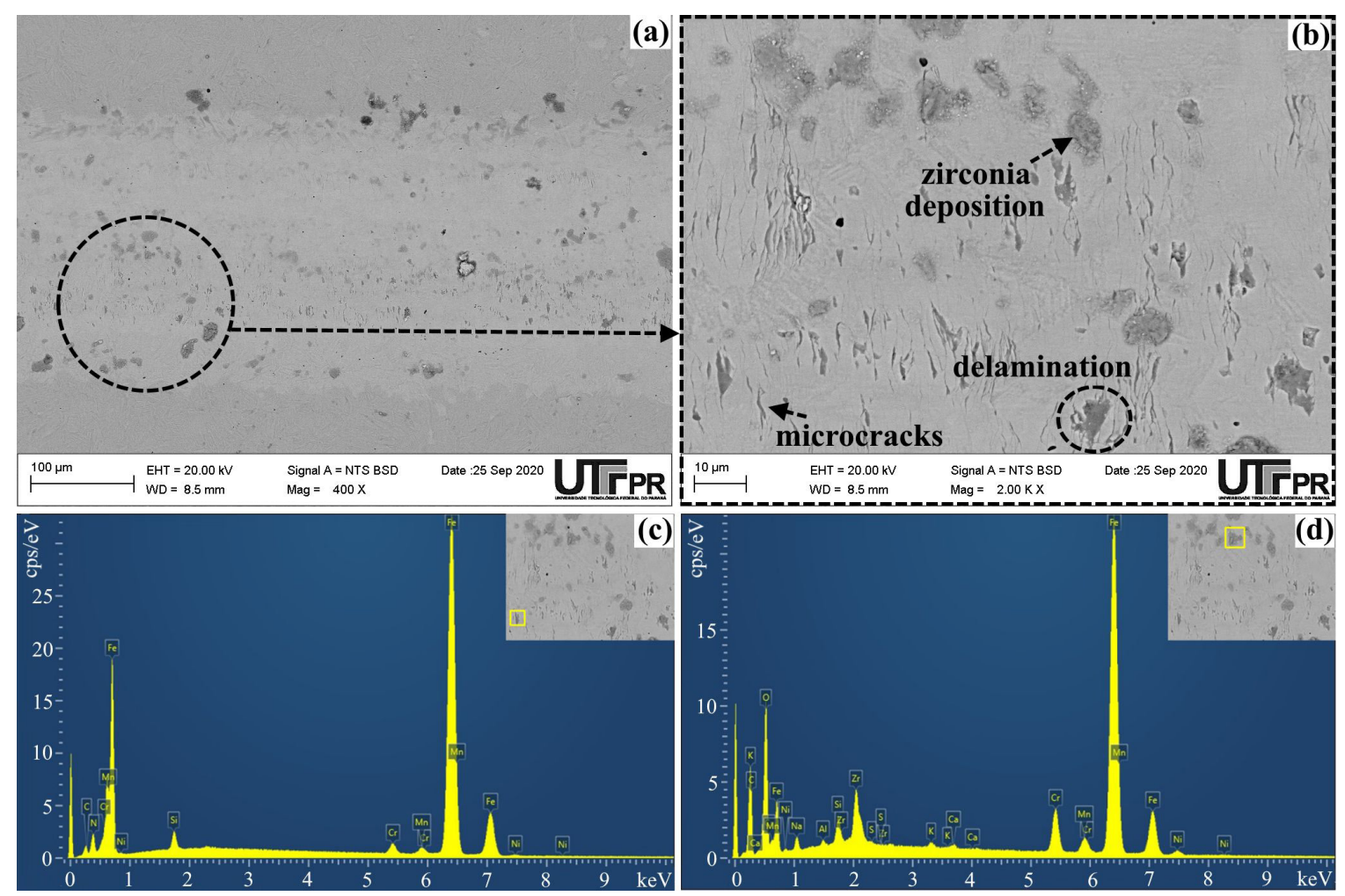

Figure 10. (a, b) SEM images and (c, d) EDS analysis of the wear tracks after reciprocal sliding wear of plasma nitrided samples for $9 \mathrm{~h}$ with gas mixture composition of $24 \mathrm{vol} . \% \mathrm{~N}_{2}$. 


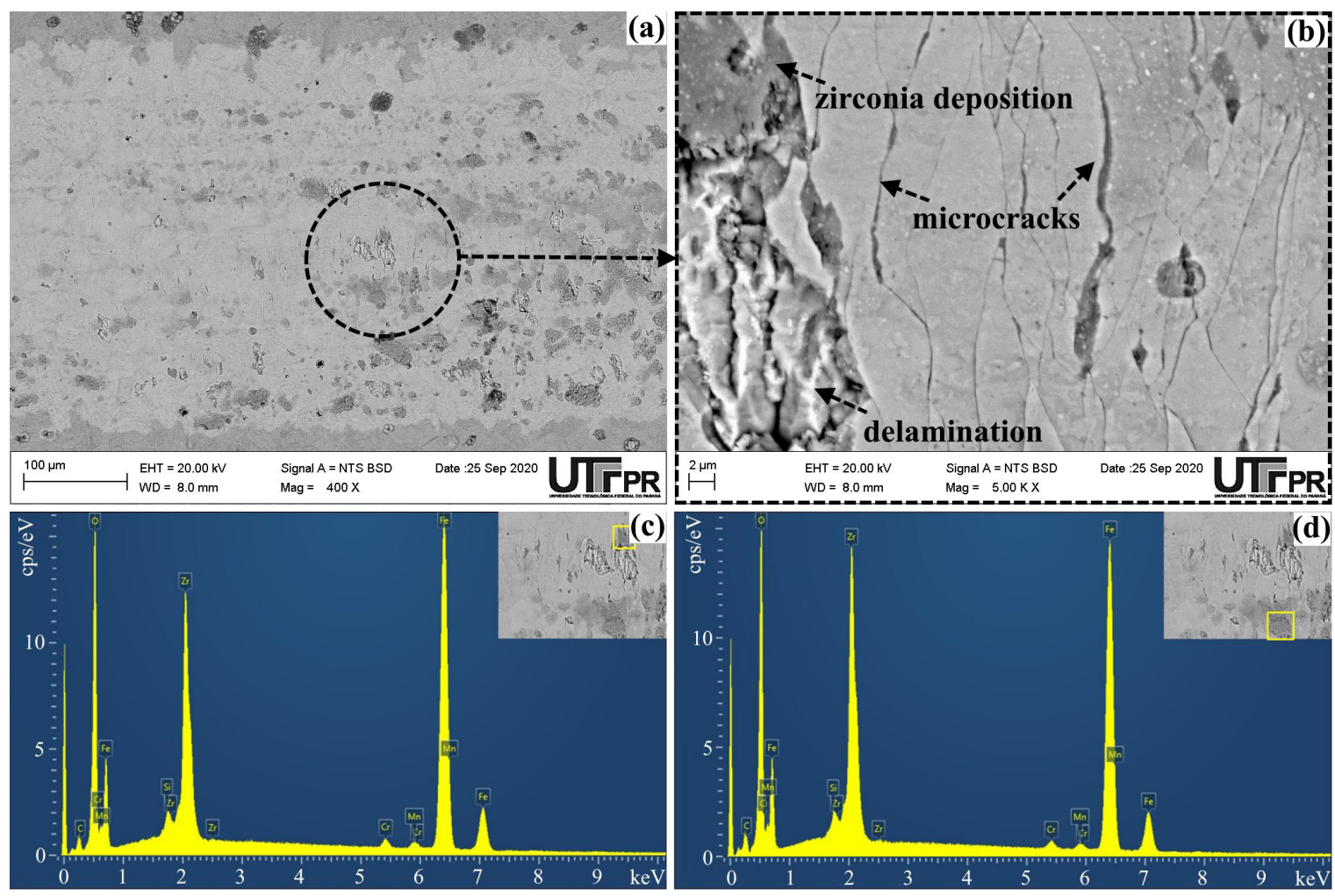

Figure 11. (a, b) SEM images and (c, d) EDS analysis of the wear tracks after reciprocal sliding wear of plasma nitrided samples for $9 \mathrm{~h}$ with gas mixture composition of 76 vol. $\% \mathrm{~N}_{2}$.

the levels of the non-nitrided samples, there was a collapse of the compound layer ${ }^{21}$.

Figures 9c, 9d, Figures 10c, 10d and Figures 11c, 11d show the EDS analyses carried out on the worn tracks after reciprocal sliding wear to identify the chemical elements present in the surface of the plasma nitrided samples, in addition to the zirconia transferred from balls to the tracks. In all the worn tracks analyzed by EDS, zirconia peaks were detected. This confirms the wear of the ball and transfer of zirconia from the ball to the wear track. The peaks associated with the core steel lose intensity in samples with thicker compound layers, that is, in plasma nitrided samples with nitrogen rich gas composition. Despite the COF level having reached the values of the non-nitrided samples, it is clear that there was no total rupture of the nitrided layer in the wear tracks, in all the studied conditions, Figures 9a, 9b, Figures 10a, 10b and Figures 11a, 11b, but in the regions where the EDS analysis do not show peaks associated with nitrogen, the removal of the compound layer occurred, Figures $9 \mathrm{c}, 9 \mathrm{~d}$, Figures 10c, 10d and Figures 11c, 11d.

It is evident in SEM images of plasma nitrided samples with a low amount of 5 vol. $\% \mathrm{~N}_{2}$ that numerous parallel scratches were developed along the sliding wear direction, see Figures 9a, 9b. The scratches mainly develop between contacting surfaces indicating an abrasive wear mechanism ${ }^{47,48}$. In addition to the tracks, fine wear debris of zirconia balls and discontinuous layers were also generated on the worn surfaces. Many microcracks are visible in the compound layer of plasma nitrided samples with gas mixture composition of 24 and 76 vol. $\% \mathrm{~N}_{2}$, see Figures 10a, 10b and Figures 11a, 11b. These inhomogeneous distributions of the wear debris of the compound layer contribute to the significant fluctuations of friction coefficients as displayed in Figures 7a-c.

Studies developed by Dalcin et al. ${ }^{21}$ show that despite gas mixture of 76 vol. $\% \mathrm{~N}_{2}$ can be used to improve the surface properties of the DIN 18MnCrSiMo6-4 steel. The nitrogen rich gas composition showed precipitation of nitrides, carbonitrides or carbides at grain the boundaries of plasma nitrided M2 high-speed steel ${ }^{49}$. It is known that grain boundary precipitation increases with time and temperature ${ }^{17,49}$ and that the presence of precipitation at grain boundaries results in brittleness of the diffusion zone ${ }^{49,50}$. For continuous cooling bainitic steels with low carbon content, the embrittlement of the diffusion zone does not appear to be as intense. The early formation of damage in nitrided surfaces with $76 \mathrm{vol} . \% \mathrm{~N}_{2}$ is due to the embrittlement of the compound layer, proven by the decrease in fracture toughness ${ }^{23}$.

To evaluate the statistical significance of nitrogen gas composition and treatment time variation on the case depth, surface microhardness and sliding distance at the time before the first damage were analyzed these results using the Minitab 16 software. The results of the interaction plot by analysis of variance are shown in Figures 12a-f. The interaction plot demonstrates how the relationship between a categorical factor and a continuous response depends on the value of the second categorical factor. The interaction strength is greater when the lines in the graphs are non-parallel ${ }^{51}$. 
From a statistical point of view (Table 3), it is noticed that the case depth was influenced by the nitrogen gas composition and time parameters $\left(\mathrm{P}_{\text {-Value }}=0.00<\alpha=0.05\right)$. The interaction between nitrogen gas composition and time treatment was not significant in the case depth $\left(\mathrm{P}_{\text {-Value }}=0.54\right.$ $>\alpha=0.05$ ), Figures $12 \mathrm{a}, 12 \mathrm{~b}$, that is, there was no synergistic effect in increasing of the case depth. Since increasing the nitrogen gas composition and time increases the case depth, they prevent the pile-up and the possible delamination of the surface layer ${ }^{21}$. Tukey's-b post hoc test indicated that the nitrogen gas composition with 76 vol. $\% \mathrm{~N}_{2}$ showed the higher case depth, when compared to the same nitriding times.

Figures 12c, 12d show the surface hardness of plasma nitrided samples with 5 vol. $\% \mathrm{~N}_{2}$ is less hard than plasma nitrided samples with 24 and 76 vol. $\% \mathrm{~N}_{2}$, respectively. As can be seen in Table 3 , the nitrogen gas composition showed
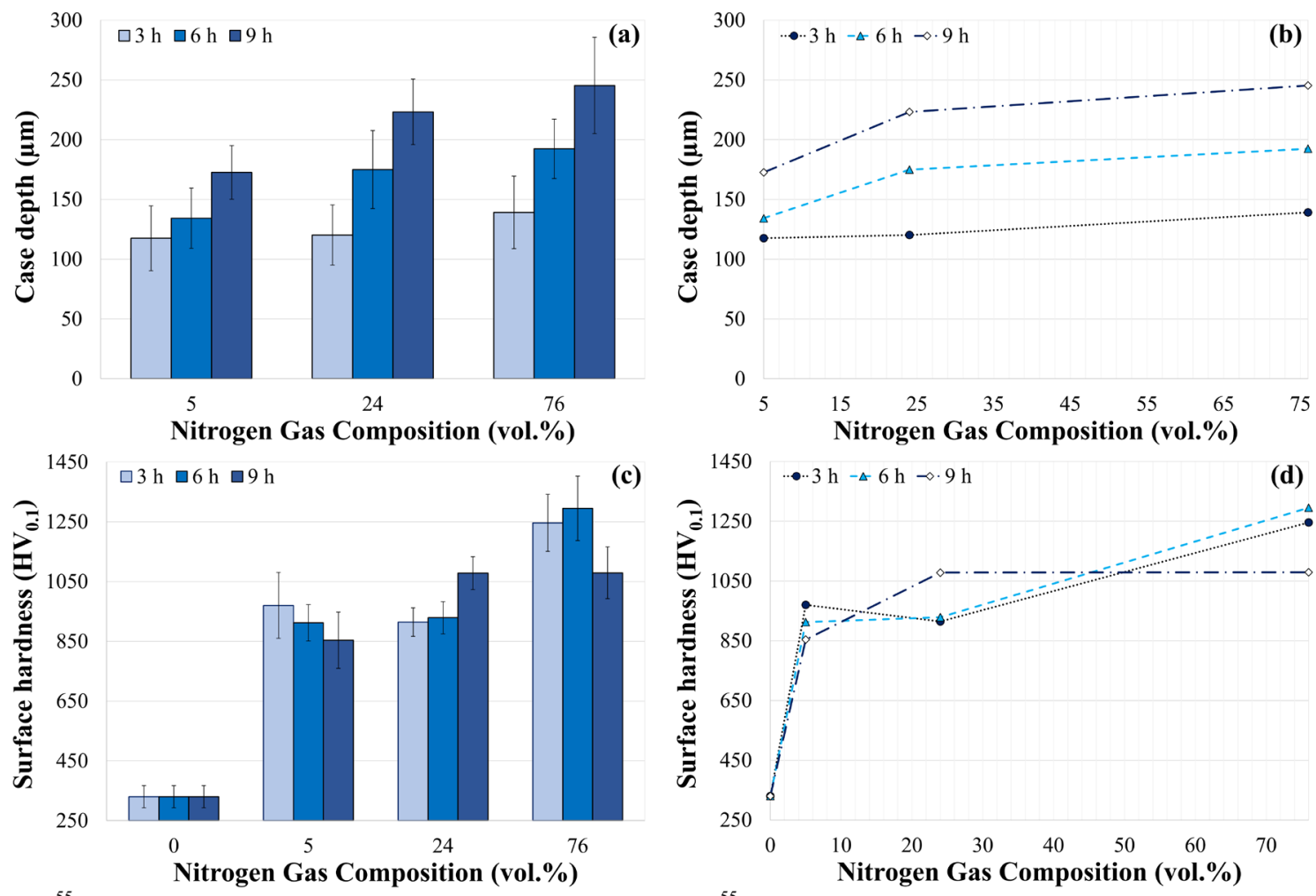

(c)
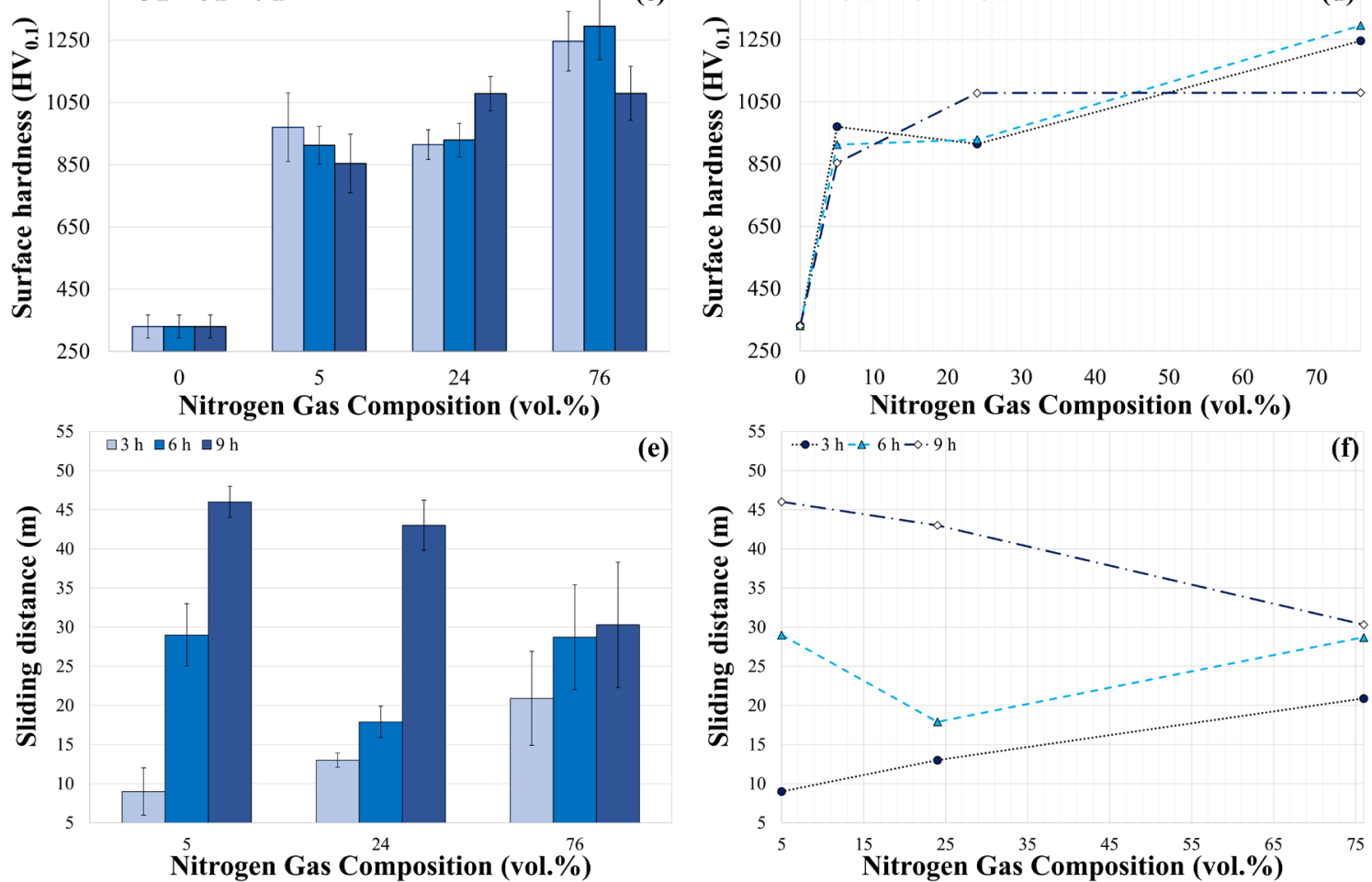

Figure 12. Interaction plot nitrogen gas composition and nitriding time with: (a, b) Case depth; (c, d) Surface hardness; (e, f) Sliding distance before microcracks formation or delamination of the surface layer.

Table 3. $P_{\text {-Value }}$ obtained through a two-way analysis of variance.

\begin{tabular}{lccc}
\hline \multicolumn{1}{c}{ Input Factor } & Case depth & Surface hardness & Sliding distance* \\
\hline Nitrogen gas composition & 0.01 & $0.00^{* *}$ & 0.20 \\
\hline Time & $0.00^{* *}$ & 0.51 & $0.00^{* *}$ \\
\hline Nitrogen gas composition*Time & 0.54 & 0.01 & $0.00^{* *}$ \\
\hline *Sliding distance before the first damage on the surface layer. **The Minitab software package displays the $\mathrm{P}_{\text {-value }}=0$ when the results tend to zero.
\end{tabular}



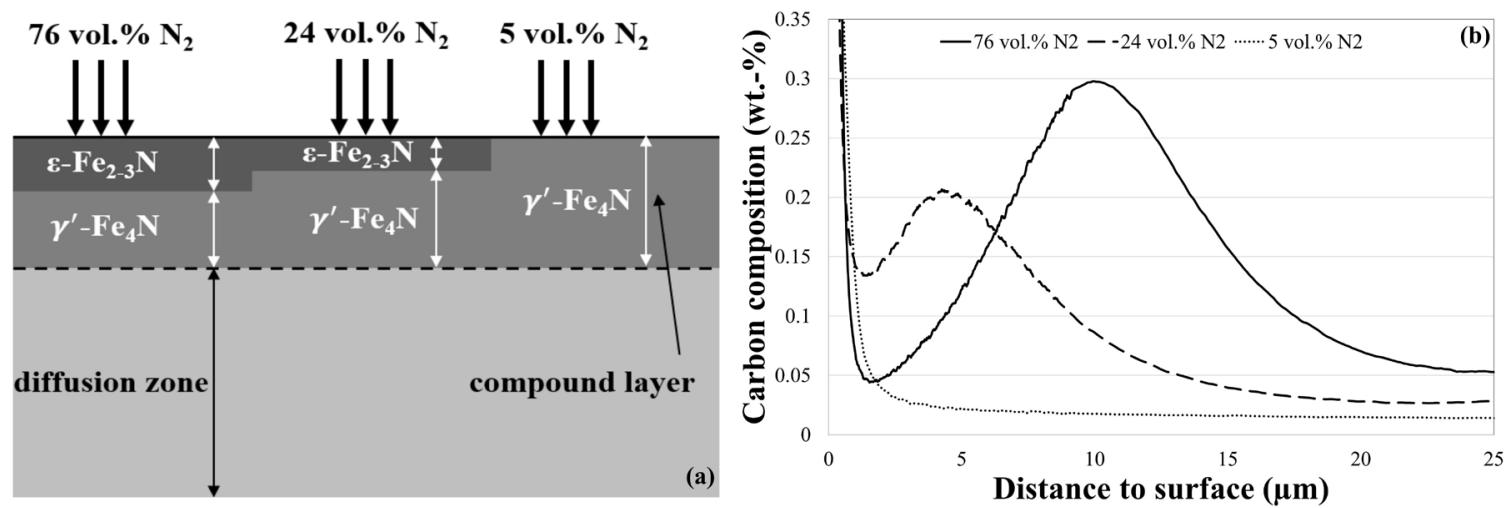

Figure 13. (a) Schematic representation of the nitrided layer; (b) Carbon composition for the plasma nitrided samples. Adapted from Dalcin et al. ${ }^{23}$.

statistical relevance $\left(\mathrm{P}_{\text {-Value }}=0.00<\alpha=0.05\right)$, but it was not possible to determine the effect of treatment time $\left(\mathrm{P}_{\text {-Value }}=\right.$ $0.51>\alpha=0.05)$. However, the synergistic effect responsible for the increase in surface hardness was present in the treatments of 3 and $6 \mathrm{~h}\left(\mathrm{P}_{\text {-value }}=0.01<\alpha=0.05\right)$, Figure $12 \mathrm{~d}$. The reduction in the surface hardness of the plasma nitrided samples for $9 \mathrm{~h}$ and with $76 \mathrm{vol} . \% \mathrm{~N}_{2}$ is probably associated with the porosity of the compound layer ${ }^{21,39}$. Regarding the surface hardness the plasma nitrided samples with 24 vol. $\%$ $\mathrm{N}_{2}$ did not show any statistically significant difference of the plasma nitrided with $5 \mathrm{vol} . \% \mathrm{~N}_{2}$ between the treatment times, Figures 12c, 12d.

The plasma nitrided samples for $9 \mathrm{~h}$ with 5 and 24 vol. $\% \mathrm{~N}_{2}$ had the best results in terms of sliding distance, Figures $12 \mathrm{e}, 12 \mathrm{f}$. Although the nitriding time and the nitrogen gas composition contributed to increase the thickness of the nitrided layer, the analysis of variance did not detect the influence of the nitrogen gas composition in the sliding distance before the increase in COF to the substrate level $\left(\mathrm{P}_{\text {-Value }}=0.20>\alpha=0.05\right)$. The nitriding time $\left(\mathrm{P}_{\text {-Value }}=0.00\right.$ $<\alpha=0.05)$ and the interaction between time and nitrogen gas composition $\left(\mathrm{P}_{\text {-Value }}=0.00<\alpha=0.05\right)$ contributed to the increase the first damage resistance of all samples, Figures $12 \mathrm{e}, 12 \mathrm{f}$. The synergistic effect of the nitrogen composition in the gas mixture and the $9 \mathrm{~h}$ time impaired the wear resistance of the compound layer of the samples nitrided to plasma with $76 \mathrm{vol} . \% \mathrm{~N}_{2}$, due to the predominant formation of the $\varepsilon-\mathrm{Fe}_{2-3}(\mathrm{C}) \mathrm{N}$ phase in the compound layer and due to the carbon enrichment in the diffusion zone, causing the weakening of the subsurface ${ }^{23}$.

The plasma nitriding treatments were able to reduce friction coefficient up to the moment that microcracks and or delamination started. When the compound layer fracture process begins, the friction coefficient then exceeded measured values for the non-nitrided steel. As mentioned by previous work ${ }^{21}$, plasma nitrided samples that have a higher case depth (compound layer + diffusion zone) presented a low amount of plastic deformation. However, the plasma nitrided samples with 76 vol. $\% \mathrm{~N}_{2}$ that showed the highest layer thicknesses did not show the highest the first damage resistance. The plasma nitrided samples treated with 76 vol.\% $\mathrm{N}_{2}$ showed a biphasic compound layer $\left(\varepsilon-\mathrm{Fe}_{2-3}(\mathrm{C}) \mathrm{N}\right.$ and $\gamma$ '$\mathrm{Fe}_{4} \mathrm{~N}$ ) and a carbon enrichment beneath compound layer in the diffusion zone ${ }^{23}$, see Figures 13a, 13b. Both led to a decrease in fracture toughness ${ }^{23}$ as well the worse wear results for this condition as microcracks and delamination appears, see Figures 11a, 11b, especially after $9 \mathrm{~h}$ treatment.

Although no tribological tests were carried out with variations in loads and test durations to determine the acting wear mechanism ${ }^{52}$ with greater precision, the statistical analysis shows that the best performance in reciprocating dry sliding wear tests were achieved, both by treatments using 5 or 24 vol.\% $\mathrm{N}_{2}$ for $9 \mathrm{~h}$. However, comparing the plasma nitrided samples nitrided with 5 and 24 vol. $\% \mathrm{~N}_{2}$, the case depth, the surface hardness, and the highest compressive residual stresses were obtained for $24 \mathrm{vol} . \% \mathrm{~N}_{2}$. This indicates that nitrided samples with 24 vol. $\% \mathrm{~N}_{2}$ may have greater resistance until the first damage in the compound layer and greater resistance to surface fatigue than for 5 vol. $\% \mathrm{~N}_{2}$. For applications in components such as gears the mixture of $24 \mathrm{vol} . \% \mathrm{~N}_{2}$ seems to be more interesting, but the treatment time will depend on the loading conditions and the environment in which the gears will operate.

\section{Conclusions}

- Plasma nitriding has proven to be a viable process to increase the hardness and first damage resistance of DIN 18MnCrSiMo6-4 bainitic steel. In general, the treatments with nitrogen rich gas compositions ( 76 vol. $\% \mathrm{~N}_{2}$ ) introduced more compressive residual stresses on the steel surface than the compositions of 5 and $24 \mathrm{vol} . \% \mathrm{~N}_{2}$. The nitriding time seems not to have significantly influenced the residual stresses in the diffusion zone;

- The plasma nitrided samples with 24 and 76 vol. \% $\mathrm{N}_{2}$ formed a biphasic compound layer of $\varepsilon-\mathrm{Fe}_{2-3}(\mathrm{C}) \mathrm{N}$ and $\gamma^{\prime}-\mathrm{Fe}_{4} \mathrm{~N}$. As the percentage of nitrogen in the gas mixture was decreased, the $\gamma^{\prime}-\mathrm{Fe}_{4} \mathrm{~N}$ percentage in the compound layer increased, but a monophasic compound layer was achieved only with the nitrogen composition of 5 vol. $\% \mathrm{~N}_{2}$. The surface hardness of DIN 18MnCrSiMo6-4 steel increased with increasing nitrogen content in the gas mixture, because the $\varepsilon-\mathrm{Fe}_{2-3}(\mathrm{C}) \mathrm{N}$ percentage increases. As shown in this paper, the $\varepsilon-\mathrm{Fe}_{2-3}(\mathrm{C}) \mathrm{N}$ phase is harder than the $\gamma^{\prime}-\mathrm{Fe}_{4} \mathrm{~N}$ phase; 
- The nitrogen composition and exposure time to ion bombardment "sputtering" caused an increase in the roughness of the plasma nitrided samples. The results of reciprocating wear tests showed that the compound layer significantly increases the first damage resistance due to increased surface hardness. The friction coefficient is lower on the surface of nitrided samples at the beginning of the test, due to the ceramic characteristics of the compound layer. The increase in COF over the time of the tribological test is due to the appearance of third-body particles from the wear of the zirconia ball and the compound layer. The sudden growth of $\mathrm{COF}$ is related to crack formation or delamination that exposes the diffusion zone. When the diffusion zone is reached, the friction rises and may reach or even exceed the friction of non-nitrided material;

- The results indicate that the plasma nitrided samples for $9 \mathrm{~h}$ with 5 and 24 vol.\% $\mathrm{N}_{2}$ may have better resistance until the first damage in the ball-on-flat tribometer. The plasma nitrided samples with 76 vol. $\% \mathrm{~N}_{2}$ and with greater layer thickness did not have the best results due to the embrittlement of the compound layer, proven by the decrease in fracture toughness. In sliding surfaces applications, plasma nitrided layers with 24 vol. $\% \mathrm{~N}_{2}$ would have a better performance, when compared to plasma nitrided layers with 5 vol. $\% \mathrm{~N}_{2}$.

\section{Acknowledgments}

This work was carried out with the support of CAPES, a Brazilian government entity focused on human resources training, with the support of CAPES BRAGECRIM PROGRAM (Process no. 88881.142485/2017-01 - aid number 1844/2017) and CAPES - PROEX (Process 23038.000341/2019-71). R. L. Dalcin acknowledges CAPES (Grant 88882.345854/2019-01), A. S. Rocha acknowledges CNPq (Grant 308773/2018-7), V. V. de Castro acknowledges CNPq (Grant 166262/2018-8), R. D. Torres acknowledges FINEP (Grant 01.10.632) and C. F. Malfatti acknowledges CNPq (Grant 307723/2018-6). The authors acknowledge the Laboratório de Superfícies e Contato (LASC) and Centro Multiusuário de Caracterização de Materiais (CMCM) of Universidade Tecnológica Federal do Paraná (UTFPR).

\section{References}

1. Luo Y, Peng J, Wang H, Wu X. Effect of tempering on microstructure and mechanical properties of a non-quenched bainitic steel. Mater Sci Eng A. 2010;527(15):3433-7. http:// dx.doi.org/10.1016/j.msea.2010.02.010.

2. Lembke MI, Olschewski G, Roelofs H, Klümper-Westkamp H. Nitrieren von hochfesten, bainitischen Langprodukten*. HTM. 2014;69(4):195-200. http://dx.doi.org/10.3139/105.110226.

3. Buchmayr B. Critical assessment 22: bainitic forging steels. Mater Sci Technol. 2016;32(6):517-22. http://dx.doi.org/10.1 080/02670836.2015.1114272.

4. Ivaniski TM, Souza TF, Épp J, Rocha AS. Constitutive modelling of high temperature flow behaviour for a low carbon high silicon bainitic steel. Mater Res. 2020;23(5):e20200264. http://dx.doi. org/10.1590/1980-5373-mr-2020-0264.
5. Lemos Bevilaqua W, Epp J, Meyer H, Silva Rocha A, Roelofs $H$. In situ investigation of the bainitic transformation from deformed austenite during continuous cooling in a low carbon Mn-Si-Cr-Mo steel. Metall Mater Trans, A Phys Metall Mater Sci. 2020;51(7):3627-37. http://dx.doi.org/10.1007/s11661020-05800-6.

6. Silveira ACF, Bevilaqua WL, Dias VW, Castro PJ, Epp J, Rocha AS. Influence of hot forging parameters on a low carbon continuous cooling bainitic steel microstructure. Metals. 2020;10(5):601. http://dx.doi.org/10.3390/met10050601.

7. Castro PJ, Silveira ACF, Ivaniski TM, Turra CJ, Epp J, Rocha AS. Two-step continuous cooling heat treatment applied in a low carbon bainitic steel. Mater Res. 2021;24(2):e20200334. http://dx.doi.org/10.1590/1980-5373-mr-2020-0334.

8. Hatwig RA, Dong J, Epp J, Rocha AS. Effect of compressive deformations on the final microstructure of a low carbon high silicon bainitic steel thermomechanically processed. Mater Res. 2021;24(1):e20200346. http://dx.doi.org/10.1590/1980-5373$\mathrm{mr}-2020-0346$.

9. Hasler L, Roelofs H, Lembke M, Caballero FG. New air cooled steels with outstanding impact toughness. In: 3rd International Conference on Steels in Cars and Trucks; 2011; Wolfratshausen, Germany. Proceedings. Victoria: AbeBooks; 2011.

10. García Navas V, Gonzalo O, Quintana I, Pirling T. Residual stresses and structural changes generated at different steps of the manufacturing of gears: effect of banded structures. Mater Sci Eng A. 2011;528(15):5146-57. http://dx.doi.org/10.1016/j. msea.2011.03.004.

11. Rego R, Löpenhaus F, Gomes J, Klocke F. Residual stress interaction on gear manufacturing. J Mater Process Technol. 2018;252:24958. http://dx.doi.org/10.1016/j.jmatprotec.2017.09.017.

12. Dong J, Skalecki MG, Hatwig RA, Bevilaqua WL, Stark A, Epp J, et al. Study of microstructural development of bainitic steel using eddy current and synchrotron XRD in-situ measurement techniques during thermomechanical treatment. HTM. 2020;75(1):3-22. http://dx.doi.org/10.3139/105.110402.

13. Caballero FG, Bhadeshia HKDH, Mawella KJA, Jones DG, Brown P. Design of novel high strength bainitic steels: part 2. Mater Sci Technol. 2001;17(5):517-22. http://dx.doi. org/10.1179/026708301101510357.

14. Caballero FG, Santofimia MJ, García-Mateo C, Chao J, de Andrés CG. Theoretical design and advanced microstructure in super high strength steels. Mater Des. 2009;30(6):2077-83. http://dx.doi.org/10.1016/j.matdes.2008.08.042.

15. Caballero FG, Roelofs H, Hasler S, Capdevila C, Chao J, Cornide $\mathrm{J}$, et al. Influence of bainite morphology on impact toughness of continuously cooled cementite free bainitic steels. Mater Sci Technol. 2012;28(1):95-102. http://dx.doi.org/10.11 79/1743284710Y.0000000047.

16. Caballero FG, Santofimia MJ, Capdevila C, García-Mateo C, García de Andrés C. Design of advanced bainitic steels by optimisation of TTT diagrams and T0 curves. ISIJ Int. 2006;46(10):1479-88. http://dx.doi.org/10.2355/isijinternational.46.1479.

17. Silva Rocha A, Strohaecker T, Tomala V, Hirsch T. Microstructure and residual stresses of a plasma-nitrided M2 tool steel. Surf Coat Tech. 1999;115(1):24-31. http://dx.doi.org/10.1016/ S0257-8972(99)00063-8.

18. Podgornik B, Leskovšek V, Kovačič M, Vižintin J. Analysis and prediction of residual stresses in nitrided tool steel. Mater Sci Forum. 2011;681:352-7. http://dx.doi.org/10.4028/www. scientific.net/MSF.681.352.

19. Podgornik B, Vižintin J, Leskovšek V. Tribological properties of plasma and pulse plasma nitrided AISI 4140 steel. Surf Coat Tech. 1998;108-109:454-60. http://dx.doi.org/10.1016/ S0257-8972(98)00571-4.

20. Paschke H, Weber M, Kaestner P, Braeuer G. Influence of different plasma nitriding treatments on the wear and crack behavior of forging tools evaluated by Rockwell indentation 
and scratch tests. Surf Coat Tech. 2010;205(5):1465-9. http:// dx.doi.org/10.1016/j.surfcoat.2010.07.053.

21. Dalcin RL, Rocha AS, Castro VV, Oliveira LF, Neves JCK, Silva $\mathrm{CH}$, et al. Influence of plasma nitriding with a nitrogen rich gas composition on the reciprocating sliding wear of a DIN 18MnCrSiMo6-4 steel. Mater Res. 2021;24(4):e20200592. http://dx.doi.org/10.1590/1980-5373-mr-2020-0592.

22. Dalcin RL, Oliveira LF, Diehl IL, Dias VW, Rocha AS. Response of a DIN 18MnCrSiMo6-4 continuous cooling bainitic steel to plasma nitriding with a nitrogen rich gas composition. Mater Res. 2020;23(2):e20200036. http://dx.doi.org/10.1590/19805373-mr-2020-0036.

23. Dalcin RL, Oliveira LF, Diehl CATS, Silva Rocha A. Response of a DIN 18MnCrSiMo6-4 Continuous cooling bainitic steel to different plasma nitriding gas mixtures. Mater Res. 2020;23(5):e20200269. http://dx.doi.org/10.1590/1980-5373mr-2020-0269.

24. Alsaran A, Karakan M, Çelik A. The investigation of mechanical properties of ion-nitrided AISI 5140 low-alloy steel. Mater Charact. 2002;48(4):323-7. http://dx.doi.org/10.1016/S10445803(02)00275-9.

25. Gražulis S, Daškevič A, Merkys A, Chateigner D, Lutterotti L, Quirós M, et al. Crystallography Open Database (COD): an open-access collection of crystal structures and platform for worldwide collaboration. Nucleic Acids Res. 2012;40(D1):D420-7. http://dx.doi.org/10.1093/nar/gkr900.

26. Karlsruhe ICSD. Basic search \& retrieve [Internet]. 2020 [cited 2021 Sept 5]. Available from: https://icsd.fiz-karlsruhe.de/index. xhtml;jsessionid=19DB93C9947356A41CB36145B5302A0C

27. Doebelin N, Kleeberg R. Profex: a graphical user interface for the Rietveld refinement program BGMN. J Appl Cryst. 2015;48(5):1573-80. http://dx.doi.org/10.1107/S1600576715014685.

28. ASTM: American Society for Testing and Materials. ASTM E92: test methods for Vickers hardness and Knoop hardness of metallic materials. West Conshohocken: ASTM International; 2017.

29. DIN: Deutsches Institut für Normung. DIN 50 190: Härtetiefe wärmebehandelter Tiele: Ermittlung der Nitrierhärtetiefe. Teil 3. Berlin: DIN; 1979.

30. ISO: International Organization for Standardization . ISO 4287: geometrical product specifications (GPS) - surface texture: profile method - terms, definitions and surface texture parameters. Geneva: ISO; 2002.

31. ISO: International Organization for Standardization - ISO. ISO 4288: geometrical product specifications (GPS) - surface texture: profile method - rules and procedures for the assessment of surface texture. Geneva: ISO; 2008.

32. ASTM: American Society for Testing and Materials. ASTM G133: test method for linearly reciprocating ball-on-flat sliding wear. West Conshohocken: ASTM International; 2005. https:// doi.org/10.1520/G0133-05R16.

33. Ilhan-Sungur E, Çotuk A. Microbial corrosion of galvanized steel in a simulated recirculating cooling tower system. Corros Sci. 2010;52(1):161-71. http://dx.doi.org/10.1016/j. corsci.2009.08.049.

34. Kovács D, Quintana I, Dobránszky J. Effects of different variants of plasma nitriding on the properties of the nitrided layer. J Mater Eng Perform. 2019;28(9):5485-93. http://dx.doi. org/10.1007/s11665-019-04292-9.

35. Cullity BD. Elements of x-ray diffraction. 2nd ed. Reading: Addison-Wesley Pub. Co.; 1978.

36. Loh NL, Siew LW. Residual stress profiles of plasma nitrided steels. Surf Eng. 1999;15(2):137-42. http://dx.doi. org/10.1179/026708499101516489.

37. Leskovšek V, Podgornik B, Nolan D. Modelling of residual stress profiles in plasma nitrided tool steel. Mater Charact. 2008;59(4):454-61. http://dx.doi.org/10.1016/j.matchar.2007.03.009.
38. Lee I, Park I. Microstructures and mechanical properties of surface-hardened layer produced on SKD 61 steel by plasma radical nitriding. Mater Sci Eng A. 2007;449-451:890-3. http:// dx.doi.org/10.1016/j.msea.2006.02.412.

39. Nolan D, Leskovsek V, Jenko M. Estimation of fracture toughness of nitride compound layers on tool steel by application of the Vickers indentation method. Surf Coat Tech. 2006;201(12):182-8. http://dx.doi.org/10.1016/j.surfcoat.2005.11.077.

40. Sun Y, Luo N, Bell T. Three-dimensional characterisation of plasma nitrided surface topography. Surf Eng. 1994;10(4):27986. http://dx.doi.org/10.1179/sur.1994.10.4.279.

41. Lampe T, Eisenberg S, Laudien G. Compound layer formation during plasma nitriding and plasma nitrocarburising. Surf Eng. 1993;9(1):69-76. http://dx.doi.org/10.1179/sur.1993.9.1.69.

42. Giacomelli RO, Salvaro DB, Bendo T, Binder C, Klein AN, Mello JDB. Topography evolution and friction coefficient of gray and nodular cast irons with duplex plasma nitrided + DLC coating. Surf Coat Tech. 2017;314:18-27. http://dx.doi. org/10.1016/j.surfcoat.2016.09.035.

43. Çomaklı O, Yetim AF, Karaca B, Çelik A. Effect of gas mixture on tribological performance of plasma nitrided grey cast iron under dry and lubricated conditions. Mater Res Express. 2019;6(5):056513. http://dx.doi.org/10.1088/2053-1591/ab012b.

44. Díaz-Guillén JC, Naeem M, Hdz-García HM, Acevedo-Davila JL, Díaz-Guillén MR, Khan MA, et al. Duplex plasma treatment of AISI D2 tool steel by combining plasma nitriding (with and without white layer) and post-oxidation. Surf Coat Tech. 2020;385:125420. http://dx.doi.org/10.1016/j.surfcoat.2020.125420.

45. Rovani AC, Breganon R, de Souza GS, Brunatto SF, Pintaúde G. Scratch resistance of low-temperature plasma nitrided and carburized martensitic stainless steel. Wear. 2017;376-377:70-6. http://dx.doi.org/10.1016/j.wear.2017.01.112.

46. Lorenzo-Martin C, Ajayi O, Erdemir A, Fenske GR, Wei R. Effect of microstructure and thickness on the friction and wear behavior of CrN coatings. Wear. 2013;302(1-2):963-71. http:// dx.doi.org/10.1016/j.wear.2013.02.005.

47. Schibicheski Kurelo BCE, Oliveira WR, Serbena FC, Souza GB. Surface mechanics and wear resistance of supermartensitic stainless steel nitrided by plasma immersion ion implantation. Surf Coat Tech. 2018;353:199-209. http://dx.doi.org/10.1016/j. surfcoat.2018.08.079.

48. Deng G, Tieu AK, Su L, Wang P, Wang L, Lan X, et al. Investigation into reciprocating dry sliding friction and wear properties of bulk CoCrFeNiMo high entropy alloys fabricated by spark plasma sintering and subsequent cold rolling processes: role of Mo element concentration. Wear. 2020;460-461:203440. http://dx.doi.org/10.1016/j.wear.2020.203440.

49. Rocha AS, Strohaecker T, Hirsch T. Effect of different surface states before plasma nitriding on properties and machining behavior of M2 high-speed steel. Surf Coat Tech. 2003;165(2):176-85. http://dx.doi.org/10.1016/S0257-8972(02)00768-5.

50. Kwietniewski C, Fontana W, Moraes C, Rocha AS, Hirsch T, Reguly A. Nitrided layer embrittlement due to edge effect on duplex treated AISI M2 high-speed steel. Surf Coat Tech. 2004;179(1):27-32. http://dx.doi.org/10.1016/S02578972(03)00795-3.

51. Noronha LC, Castro VV, Ludwig GA, Schroeder RM, Malfatti CF. Ti-Cp: eletrochemical behaviour under slurry erosion wear. J Bio Tribo Corros. 2021;7(1):8. http://dx.doi.org/10.1007/ s40735-020-00442-y.

52. Mello JDB, Binder R. A methodology to determine surface durability in multifunctional coatings applied to soft substrates. Tribol Int. 2006;39(8):769-73. http://dx.doi.org/10.1016/j. triboint.2005.07.015. 